\title{
The Effects of Participating in Recreational Activities on Quality of Life and Job Satisfaction
}

\author{
Yener Aksoy $^{1, *}$, Soner Çankaya ${ }^{2}$, M. Yalçın Taşmektepligil ${ }^{3}$ \\ ${ }^{1}$ Samsun Provincial Directorate of Youth Services and Sports, Turkey \\ ${ }^{2}$ Department of Biostatistics and Medical Informatics, Faculty of Medicine, Ordu University, Turkey \\ ${ }^{3}$ Yaşar Doğu Faculty of Sports Sciences, Ondokuz Mayis University, Turkey
}

Copyright $\odot 2017$ by authors, all rights reserved. Authors agree that this article remains permanently open access under the terms of the Creative Commons Attribution License 4.0 International License

\begin{abstract}
The aims of this study were to compare the differences and determine the relationships between the scores obtained from Minnesota job-satisfaction and quality-of-life scales applied to males' ages 18 to 40 who participate in recreational activities and those who do not. The samples of the study consisted of 282 volunteers (148 of whom participate in sports and 134 of whom do not) employed in public institutions and organisations in the City of Vezirköprü in Turkey's Samsun province. The data obtained from the scales and their subscales for the two groups were analysed through the Mann-Whitney $U$ test and Kendall's tau-b, according to the results from a Kolmogorov-Smirnov test for the normality assumption $(\mathrm{P}<0.05)$. The results showed that the perceived general life quality and job satisfaction for the individuals participating in sports were higher than those who do not participate $(\mathrm{P}<0.05)$. When the associations between life-quality and job-satisfaction total scores of all participants were examined, positive significant associations were found between life-quality total scores and job-satisfaction total scores and sub-scores (intrinsic and extrinsic satisfaction) $(\mathrm{P}<0.001)$. In conclusion, it can be said that participation in recreational activities, which are defined for these purposes as organised voluntary physical activities, has a direct influence on individuals' lifestyles and increases their quality of life and job satisfaction significantly.
\end{abstract}

Keywords Recreation, Job Satisfaction, Life Quality, Exercise

\section{Introduction}

Recreation, which involves non-obligatory activities according to current basic research approaches [1], is defined as time spent replenishing energy/resting and partaking in voluntary activities, activities done after compulsory duties and activities, such as work [2].
(Recreational program planning today. London: Scott Foresman and Company). Within this context, recreational activities form the strongest area of sports activities in terms of developing health, and a great effort is underway to make recreational activities accessible to all levels of society, with different models and applications. It is possible for sports instructors to create inviting activities by using different methods and models to attract individuals of all ages to such activities. Such efforts are important, especially in terms of young individuals. Previous studies also have indicated that participating in such recreational activities at early ages boosted the odds of continuing such activities later in life [3]. In this sense, it is very practical for sports-and-recreation groups of all kinds to be available everywhere so people can enjoy an inviting environment. Recreational activities are those that intentionally give people pleasure and reward them with recreational, fun activities. [4]

It is certain that the way to get high-quality workers at state institutions and organisations is having skilled and well-motivated personnel with high performance levels and job satisfaction. Employees in a workplace face a variety of risks and problems that can decrease their spirits and motivation, leading to poor job performance. Together with rapidly changing technology, stressful working environments, fast-paced urbanisation and worker migration, and diseases that can stress people out gradually have begun to threaten society's general health. Thus, more importance has been placed lately on social activities to boost quality of life, which includes physical and emotional vitality and is tied to a person's satisfaction with life, subjective well-being, happiness, functional competence, and social well-being [5]. In developed countries especially, the concept of quality of life, which science and management environments have focused on, has concentrated on the physical problems of from disease specifically and physical, economic, and emotional factors generally [6]. Within this context, quality of life is a concept that entails the reactions to diseases that occur within living conditions and which influence levels of personal satisfaction and reactions 
against the physical, mental, and social stresses of daily life. This concept also includes culture, value judgments, and people's personal motivations and aims [7, 8].

Health is not only about fighting disease, but also a phenomenon that aims to protect the individual, the family, and society to improve the general health of human beings, including their social and professional lives. In this respect, individuals should be encouraged to practice behaviours that protect, maintain, and develop healthy lifestyles. Today, in addition to the increase in average life expectancy, the fact that chronic diseases and those that cause stress have become more widespread, and that the vast majority of the populace has begun to complain about these diseases, has caused people to place more importance on quality of life [9].

In addition to this, since people spend most of their time at work, they expect their workplace environment to meet at least some part of their life-satisfaction and social needs. Thus, workplace environment can be defined as a factor that affects a person's general life satisfaction and health. Features such as being eager to produce in the workplace, trying to develop oneself and building good relationships are positive reflections of job satisfaction in workers. On the other hand, employees' working life is a process that not only influences individuals' economic conditions, but also their psychological well-being. Within this context, individuals who satisfy their expectations in the workplace can be both economically and psychologically happier [10], while dissatisfaction can cause negative behaviours such as avoiding workplace issues, leaving a job, leading to complaining, criticising other workers, turning in substandard work, absenteeism, and even physical violence in advanced stages [11]. Many people feel both dissatisfied with their jobs and perceive a decreased quality of life due to a great number of problems they face in their workplaces. Thus, to serve people better, employers should try to decrease employees' dissatisfaction with their jobs and improve their quality-of-life conditions. At this point, the conclusions of some researchers that 'job-satisfaction levels of employees who do sports are higher than those who do not' [12] strengthen the idea that recreational activities can produce similar results.

The aims of this study are to compare the differences and determine the relationships between the scores obtained from the Minnesota job-satisfaction and quality-of-life scales in men ages 18 to 40 , some of whom participate in recreational activities and some of whom don't.

\section{Materials and Methods}

The subjects in the study consisted of 282 male volunteers (148 of whom participate in sports activities and 134 of whom don't) ages 18 to 40 who work in public institutions and organisations in the City of Vezirköprü in Turkey's Samsun province. The Quality of Life Scale (QOLS) and the
Minnesota Job Satisfaction Scale (MJSS) were used on the male subjects. The QOLS (QOLS- Short Form-SF 36) was developed by the Rand Corporation in 1992 to evaluate the life quality of individuals [13]. It was checked for validity and reliability in Turkey by Kocyigit et al. [14]. The QOLS consists of 35 items that measure eight dimensions: physical function (10 items), social function ( 2 items), role limitations related to physical problems (4 items), role limitations related to emotional problems (3 items), mental health (5 items), energy/vitality (4 items), pain (2 items), and general perception of health (5 items). It evaluates health on a scale of $0-100$, with 0 indicating a bad state of health and 100 indicating a good state of health. The QOLS scores are structured so that a higher score indicates a higher quality of life. The average total score for healthy populations is roughly 90 [15]. The Minnesota Job Satisfaction Scale, used to measure the job-satisfaction levels of personnel and developed by Weiss et al. [16] as the short version of the MSQ, is a 5-point Likert-type scale that contains 20 items (1-5 scale, with 1 for completely unsatisfied and 5 for very satisfied). This scale has been widely used in the literature and is a well-known gauge that's been shown to be stable over time, with previous research yielding excellent coefficient alphas. A point value of 25 or below indicates low job satisfaction, 26-74 indicates medium job satisfaction, and 75 and above indicates high job satisfaction [16].

\subsection{Statistical Analysis}

Cronbach's alpha internal consistency coefficients on the answers that participants gave to the items were firstly calculated. The data (Quality of Life Scale and Minnesota Job Satisfaction Scale scores) were secondly analyzed using Levene's test and the Kolmogorov- Smirnov test for equality of variance and for normality assumption, respectively $(\mathrm{P}<0.05)$. Thirdly, Mann Whitney $\mathrm{U}$ test were applied to determine whether there were differences between the scale and sub-dimension total scores of the participants who participate in recreational activities and those who do not for the Quality of Life Scale and Minnesota Job Satisfaction Scale. Finally, the relationships between the total scores from the Quality of Life Scale and Minnesota Job Satisfaction Scale and the sub-dimensions were calculated with Kendall's tau-b correlation coefficient. According to this test results, the findings were expressed as a sample size, mean with standard deviation, median, IQR (interquartile range) and minimum and maximum values. The results were accepted as significant at the level of $\mathrm{P}<0.05$. All the statistical calculations were made with the SPSS $22.0 \mathrm{~V}$. statistical program.

\section{Results}

As a result of the reliability analysis (Cronbach's alpha), which was conducted to determine the internal consistency 
of the answers given on the items in the scales used in the study, the reliability coefficient of the Quality of Life Scale was found to be 0.862 , while the reliability coefficient of the Minnesota Job Satisfaction Scale was found to be 0.921 (Table 1). These values are above 0.70 , which is considered sufficient for a study to be considered reliable [17].

A significant difference was found in the sub-dimensions of Life Quality Scale of those who participated in recreational activities and who did not $(\mathrm{P}<0.001)$.

Of the individuals in the study, the quality-of-life total scores were found to be higher in those who participated in sports activities than the scores of those who did not. When the quality-of-life dimension scores of individuals who participated in recreational activities were analysed, it was found that the highest scores were taken from the dimension of physical function, while the lowest scores were taken from the dimension of mental health. When the quality-of-life dimension scores of individuals who did not participate in recreational activities were analysed, it was found that the highest scores were taken from the dimension of pain, while the lowest scores were taken from the dimension of vitality. When the scores of the dimensions of physical function $(\mathrm{P}=0.01)$, physical role $(\mathrm{P}=0.016)$, and emotional role $(\mathrm{P}=0.048)$ were examined, it was found that the quality-of-life levels of individuals who participated in recreational activities were higher than those who did not.
In addition, when participants' scores on job satisfaction were analysed, a significant difference was found in favor of individuals who participated in recreational activities in terms of both general job satisfaction and the sub-dimensions (internal and external job satisfaction) $(\mathrm{P}<0.001)$ (Table2).

Table 1. Internal Consistency Coefficients of Quality of Life Minnesota Job Satisfaction Scales

\begin{tabular}{|c|c|c|}
\hline Scales and sub-dimensions & Items & $\begin{array}{c}\text { Cronbach } \\
\text { Alpha's }\end{array}$ \\
\hline Job satisfaction Scale & 20 & 0.921 \\
\hline Internal Job Satisfaction & 12 & 0.881 \\
\hline External Job Satisfaction & 8 & 0.851 \\
\hline Quality of Life Scale & 35 & 0.862 \\
\hline Physical Function & 10 & 0.907 \\
\hline Physical Role & 4 & 0.742 \\
\hline Pain & 2 & 0.654 \\
\hline General perception of health & 5 & 0.630 \\
\hline Vitality & 4 & 0.634 \\
\hline Social Function & 2 & 0.573 \\
\hline Emotional role & 3 & 0.702 \\
\hline Mental health & 5 & 0.708 \\
\hline
\end{tabular}


Table 2. Quality of life and job satisfaction levels of the participants

\begin{tabular}{|c|c|c|c|c|c|c|c|c|}
\hline Groups & $\mathrm{n}$ & Mean & SD & Median & IQR & Min & Max & P-value \\
\hline \multicolumn{9}{|c|}{ Quality of Life Scale sub-dimensions } \\
\hline \multicolumn{9}{|c|}{ Physical Function (PF) } \\
\hline Non-recreation & 134 & 73.06 & 24.45 & 80.00 & 25.00 & 0 & 100 & \multirow{2}{*}{0.001} \\
\hline Participants in recreation & 148 & 80.47 & 22.64 & 90.00 & 40.00 & 0 & 100 & \\
\hline \multicolumn{9}{|c|}{ Physical role (PR) } \\
\hline Non-recreation & 134 & 66.98 & 34.77 & 75.00 & 50.00 & 0 & 100 & \multirow{2}{*}{0.016} \\
\hline Participants in recreation & 148 & 75.68 & 32.73 & 100.00 & 50.00 & 0 & 100 & \\
\hline \multicolumn{9}{|c|}{ Pain $(\mathrm{P})$} \\
\hline Non-recreation & 134 & 75.87 & 23.09 & 81.50 & 41.50 & 21 & 100 & \multirow{2}{*}{0.743} \\
\hline Participants in recreation & 148 & 75.90 & 20.32 & 81.50 & 34.63 & 0 & 100 & \\
\hline \multicolumn{9}{|c|}{ General perception of health (GPOH) } \\
\hline Non-recreation & 134 & 61.35 & 19.24 & 65.00 & 27.00 & 5 & 92 & \multirow{2}{*}{0.444} \\
\hline Participants in recreation & 148 & 64.66 & 13.67 & 62.00 & 22.25 & 30 & 97 & \\
\hline \multicolumn{9}{|c|}{ Vitality (V) } \\
\hline Non-recreation & 134 & 54.55 & 20.85 & 55.00 & 21.25 & 0 & 90 & \multirow{2}{*}{0.189} \\
\hline Participants in recreation & 148 & 59.73 & 14.61 & 60.00 & 23.75 & 15 & 95 & \\
\hline \multicolumn{9}{|c|}{ Social Function (SF) } \\
\hline Non-recreation & 134 & 72.20 & 22.92 & 75.00 & 37.50 & 25 & 100 & \multirow{2}{*}{0.704} \\
\hline Participants in recreation & 148 & 71.28 & 22.37 & 75.00 & 37.50 & 25 & 100 & \\
\hline \multicolumn{9}{|c|}{ Emotional role (EM) } \\
\hline Non-recreation & 134 & 65.67 & 38.77 & 67.67 & 66.67 & 0 & 100 & \multirow{2}{*}{0.048} \\
\hline Participants in recreation & 148 & 75.00 & 32.50 & 100.00 & 33.33 & 0 & 100 & \\
\hline \multicolumn{9}{|c|}{ Mental health (MH) } \\
\hline Non-recreation & 134 & 55.55 & 18.06 & 56.00 & 28.00 & 0 & 84 & \multirow{2}{*}{0.586} \\
\hline Participants in recreation & 148 & 56.70 & 15.26 & 56.00 & 16.00 & 24 & 100 & \\
\hline \multicolumn{9}{|c|}{ Quality of life total score (QOLTS) } \\
\hline Non-recreation & 134 & 65.66 & 16.60 & 67.76 & 22.05 & 0 & 100 & \multirow{2}{*}{0.034} \\
\hline Participants in recreation & 148 & 69.93 & 13.27 & 72.77 & 14.72 & 0 & 100 & \\
\hline \multicolumn{9}{|c|}{ Job satisfaction sub-dimensions } \\
\hline \multicolumn{9}{|c|}{ Internal Satisfaction (IS) } \\
\hline Non-recreation & 134 & 38.06 & 8.89 & 38.00 & 12.00 & 12 & 52 & \multirow{2}{*}{$<0.001$} \\
\hline Participants in recreation & 148 & 42.22 & 7.71 & 44.00 & 10.00 & 19 & 59 & \\
\hline \multicolumn{9}{|c|}{ External Satisfaction (ES) } \\
\hline Non-recreation & 134 & 22.09 & 6.21 & 23.00 & 7.00 & 8 & 35 & \multirow{2}{*}{$<0.001$} \\
\hline Participants in recreation & 148 & 25.74 & 5.67 & 26.00 & 8.00 & 9 & 38 & \\
\hline \multicolumn{9}{|c|}{ Job satisfaction total score (JSTS) } \\
\hline Non-recreation & 134 & 60.15 & 14.25 & 61.00 & 18.00 & 20 & 87 & $<0001$ \\
\hline Participants in recreation & 148 & 67.96 & 12.34 & 68.50 & 15.75 & 30 & 94 & $<0.001$ \\
\hline
\end{tabular}

When the associations between quality-of-life and job-satisfaction total scores of all the participants in the study were analysed, positive significant associations were found between quality-of-life total score and job-satisfaction total score and the sub-dimensions (internal and external job satisfaction) $(\mathrm{P}<0.001)$. Similarly, positive significant associations were found between physical role, vitality, social function and emotional-role scores on the quality-of-life scale. Conversely, when the dimensions of the quality-of-life scale were analysed on their own, no significant difference was found between the dimensions of physical role and vitality. A $56.3 \%$ positive significant association was found between internal job satisfaction and external job satisfaction scores (Table 3). 
Table 3. Correlations between participants' quality of life and job satisfaction levels

\begin{tabular}{|c|c|c|c|c|c|c|c|c|c|c|c|c|}
\hline $\begin{array}{l}\text { General Correlations - } \\
\text { Kendall's-Tau b }\end{array}$ & & $\mathrm{PF}^{*}$ & FR & $\mathrm{P}$ & GPOH & $\mathrm{V}$ & $\mathrm{SF}$ & ER & MH & QOLTS & (IS) & (ES) \\
\hline \multirow{2}{*}{ Physical Role (PR) } & $\mathrm{r}$ & 0.263 & & & & & & & & & & \\
\hline & $\mathrm{p}$-values & $<0.001$ & & & & & & & & & & \\
\hline \multirow{2}{*}{ Pain (P) } & $\mathrm{r}$ & 0.119 & 0.154 & & & & & & & & & \\
\hline & $\mathrm{p}$-values & 0.007 & 0.001 & & & & & & & & & \\
\hline \multirow{2}{*}{$\begin{array}{c}\text { General Perception of } \\
\text { Health }(\mathrm{GPOH})\end{array}$} & $\mathrm{r}$ & 0.263 & 0.056 & 0.240 & & & & & & & & \\
\hline & $\mathrm{p}$-values & $<0.001$ & .224 & $<0.001$ & & & & & & & & \\
\hline \multirow{2}{*}{ Vitality (V) } & $\mathrm{r}$ & 0.171 & 0.085 & 0.114 & 0.276 & & & & & & & \\
\hline & p-values & $<0.001$ & 0.069 & 0.010 & $<0.001$ & & & & & & & \\
\hline \multirow{2}{*}{ Social Function (SF) } & $\mathrm{r}$ & 0.252 & 0.257 & 0.444 & 0.184 & 0.183 & & & & & & \\
\hline & p-values & $<0.001$ & $<0.001$ & $<0.001$ & $<0.001$ & $<0.001$ & & & & & & \\
\hline \multirow{2}{*}{ Emotional Role (ER) } & $\mathrm{r}$ & 0.206 & 0.410 & 0.134 & 0.148 & 0.143 & 0.294 & & & & & \\
\hline & p-values & $<0.001$ & $<0.001$ & 0.005 & 0.001 & 0.003 & $<0.001$ & & & & & \\
\hline \multirow{2}{*}{ Mental Health (MH) } & $\mathrm{r}$ & 0.205 & 0.213 & 0.168 & 0.259 & 0.404 & 0.326 & 0.179 & & & & \\
\hline & p-values & $<0.001$ & $<0.001$ & $<0.001$ & $<0.001$ & $<0.001$ & $<0.001$ & $<0.001$ & & & & \\
\hline \multirow{2}{*}{$\begin{array}{l}\text { Quality of life total } \\
\text { score (QOLTS) }\end{array}$} & $\mathrm{r}$ & 0.432 & 0.517 & 0.383 & 0.357 & 0.344 & 0.532 & 0.536 & 0.434 & & & \\
\hline & p-values & $<0.001$ & $<0.001$ & $<0.001$ & $<0.001$ & $<0.001$ & $<0.001$ & $<0.001$ & $<0.001$ & & & \\
\hline \multirow{2}{*}{$\begin{array}{l}\text { Internal satisfaction } \\
\text { (IS) }\end{array}$} & $\mathrm{r}$ & 0.084 & 0.194 & -0.040 & -0.016 & 0.157 & 0.106 & 0.204 & 0.102 & 0.155 & & \\
\hline & $\mathrm{p}$-values & 0.048 & $<0.001$ & 0.349 & 0.699 & $<0.001$ & 0.016 & $<0.001$ & 0.016 & $<0.001$ & & \\
\hline \multirow{2}{*}{$\begin{array}{l}\text { External satisfaction } \\
\text { (ES) }\end{array}$} & $\mathrm{r}$ & 0.066 & 0.136 & 0.060 & -0.054 & 0.128 & 0.110 & 0.217 & 0.027 & 0.143 & 0.563 & \\
\hline & p-values & 0.126 & 0.003 & 0.163 & 0.197 & 0.003 & 0.012 & $<0.001$ & 0.527 & $<0.001$ & $<0.001$ & \\
\hline \multirow{2}{*}{$\begin{array}{l}\text { Job satisfaction total } \\
\text { Score (JSTS) }\end{array}$} & $\mathrm{r}$ & 0.077 & 0.177 & 0.003 & -0.025 & 0.156 & 0.116 & 0.222 & 0.071 & 0.164 & 0.825 & 0.763 \\
\hline & p-values & 0.068 & $<0.001$ & 0.945 & 0.553 & $<0.001$ & 0.008 & $<0.001$ & 0.092 & $<0.001$ & $<0.001$ & $<0.001$ \\
\hline
\end{tabular}

* Physical Function

Table 4. Associations between the quality-of-life and job satisfaction levels of individuals who did not participate in recreation

\begin{tabular}{|c|c|c|c|c|c|c|c|c|c|c|c|c|}
\hline Non-recreation & & $\mathrm{PF}$ & PR & $\mathrm{P}$ & GPOH & $\mathrm{V}$ & SF & ER & MH & QOLTS & IJS & EJS \\
\hline \multirow{2}{*}{ Physical role (PR) } & $\mathrm{r}$ & 0.247 & & & & & & & & & & \\
\hline & p-values & $<0.001$ & & & & & & & & & & \\
\hline \multirow{2}{*}{ Pain (P) } & $\mathrm{r}$ & 0.023 & 0.150 & & & & & & & & & \\
\hline & p-values & 0.718 & 0.028 & & & & & & & & & \\
\hline \multirow{2}{*}{$\begin{array}{l}\text { General perception of } \\
\text { health }(\mathrm{GPOH})\end{array}$} & $\mathrm{r}$ & 0.365 & 0.025 & 0.287 & & & & & & & & \\
\hline & p-values & $<0.001$ & 0.703 & $<0.001$ & & & & & & & & \\
\hline \multirow{2}{*}{ Vitality (V) } & $\mathrm{r}$ & 0.311 & 0.159 & 0.151 & 0.328 & & & & & & & \\
\hline & p-values & $<0.001$ & 0.018 & 0.020 & $<0.001$ & & & & & & & \\
\hline \multirow{2}{*}{ Social function (SF) } & $\mathrm{r}$ & 0.087 & 0.323 & 0.429 & 0.249 & 0.332 & & & & & & \\
\hline & $\mathrm{p}$-values & 0.182 & $<0.001$ & $<0.001$ & $<0.001$ & $<0.001$ & & & & & & \\
\hline \multirow{2}{*}{ Emotional role (ER) } & $\mathrm{r}$ & 0.175 & 0.369 & 0.169 & 0.241 & 0.236 & 0.455 & & & & & \\
\hline & p-values & 0.011 & $<0.001$ & 0.015 & $<0.001$ & 0.001 & $<0.001$ & & & & & \\
\hline \multirow{2}{*}{ Mental health (MH) } & $\mathrm{r}$ & 0.263 & 0.258 & 0.131 & 0.200 & 0.487 & 0.406 & 0.224 & & & & \\
\hline & p-values & $<0.001$ & $<0.001$ & 0.041 & 0.001 & $<0.001$ & $<0.001$ & 0.001 & & & & \\
\hline \multirow{2}{*}{$\begin{array}{l}\text { Quality of life total score } \\
\text { (QOLTS) }\end{array}$} & $\mathrm{r}$ & 0.365 & 0.508 & 0.373 & 0.396 & 0.462 & 0.612 & 0.592 & 0.467 & & & \\
\hline & p-values & $<0.001$ & $<0.001$ & $<0.001$ & $<0.001$ & $<0.001$ & $<0.001$ & $<0.001$ & $<0.001$ & & & \\
\hline \multirow{2}{*}{$\begin{array}{l}\text { Internal job satisfaction } \\
\text { (IJS) }\end{array}$} & $\mathrm{r}$ & -0.029 & 0.176 & -0.160 & -0.068 & 0.165 & 0.055 & 0.136 & 0.147 & 0.067 & & \\
\hline & p-values & 0.639 & 0.008 & 0.011 & 0.265 & 0.008 & 0.388 & 0.044 & 0.018 & 0.264 & & \\
\hline \multirow{2}{*}{$\begin{array}{l}\text { External job satisfaction } \\
\text { (EJS) }\end{array}$} & $\mathrm{r}$ & -0.066 & 0.134 & -0.042 & -0.153 & 0.101 & 0.085 & 0.176 & 0.076 & 0.070 & 0.587 & \\
\hline & p-values & 0.288 & 0.043 & 0.504 & 0.013 & 0.105 & 0.186 & 0.009 & 0.224 & 0.242 & $<0.001$ & \\
\hline \multirow{2}{*}{$\begin{array}{l}\text { Job satisfaction total } \\
\text { Score (JST) }\end{array}$} & $\mathrm{r}$ & -0.053 & 0.169 & -0.100 & -0.099 & 0.149 & 0.075 & 0.163 & 0.130 & 0.077 & 0.835 & 0.773 \\
\hline & p-values & 0.394 & 0.010 & 0.109 & 0.104 & 0.016 & 0.239 & 0.015 & 0.035 & 0.198 & $<0.001$ & $<0.001$ \\
\hline
\end{tabular}


When the associations between the quality-of-life and job-satisfaction total scores of the subjects who did not participate in recreational activities were analysed, no significant associations were found between quality-of-life total score and job-satisfaction total score and the sub-dimensions (internal and external job satisfaction) $(\mathrm{P}>0.05)$. On the other hand, positive significant associations were found between job satisfaction and physical role, vitality, emotional role, and mental health scores $(\mathrm{P}<0.05)$. When the dimensions of the quality-of-life scale were analysed on their own, no significant difference was found between physical function and pain and social function scores and physical role and general perception of health total scores $(\mathrm{P}>0.05)$. A $58.7 \%$ positive significant association was found between internal job satisfaction and external job satisfaction scores (Table 4).

When the associations between the quality-of-life and job-satisfaction total scores of the participants who participate in recreational activities were analysed, positive significant associations were found between quality-of-life and job-satisfaction total scores and sub-dimensions (internal and external job satisfaction) $(\mathrm{P}<0.001)$. Similarly, positive significant associations were found between job-satisfaction and quality-of-life dimensions, except scores on general perceptions of physical and mental health $(\mathrm{P}<0.05)$. Conversely, when the dimensions of the quality-of-life scale were analysed on their own, the associations between all dimensions except physical and emotional role, vitality and physical function, and pain and emotional role were found to be significant $(\mathrm{P}<0.05)$. A $52.9 \%$ positive significant association was found between internal job satisfaction and external job satisfaction scores (Table 5).

Table 5. Associations between the quality-of-life and job-satisfaction levels of individuals who participated in recreation

\begin{tabular}{|c|c|c|c|c|c|c|c|c|c|c|c|c|}
\hline Participant in recreation & & $\mathrm{PF}$ & PR & $\mathrm{P}$ & $\mathrm{GPOH}$ & $\mathrm{V}$ & SF & ER & MH & QOLT & IS & ES \\
\hline \multirow{2}{*}{ Physical role (PR) } & $\mathrm{r}$ & 0.282 & & & & & & & & & & \\
\hline & p-values & $<0.001$ & & & & & & & & & & \\
\hline \multirow{2}{*}{ Pain $(\mathrm{P})$} & $\mathrm{r}$ & 0.205 & 0.172 & & & & & & & & & \\
\hline & p-values & 0.001 & 0.009 & & & & & & & & & \\
\hline \multirow{2}{*}{$\begin{array}{l}\text { General perception of } \\
\text { health }(\mathrm{GPOH})\end{array}$} & $\mathrm{r}$ & 0.178 & 0.089 & 0.217 & & & & & & & & \\
\hline & p-values & 0.004 & 0.168 & $<0.001$ & & & & & & & & \\
\hline \multirow{2}{*}{ Vitality (V) } & $\mathrm{r}$ & 0.029 & $<0.001$ & 0.090 & 0.223 & & & & & & & \\
\hline & p-values & 0.642 & 0.996 & 0.140 & $<0.001$ & & & & & & & \\
\hline \multirow{2}{*}{ Social function (SF) } & $\mathrm{r}$ & 0.419 & 0.205 & 0.472 & 0.145 & 0.040 & & & & & & \\
\hline & $\mathrm{p}$-values & $<0.001$ & 0.002 & $<0.001$ & 0.019 & 0.525 & & & & & & \\
\hline \multirow{2}{*}{ Emotional role (ER) } & $\mathrm{r}$ & 0.231 & 0.446 & 0.104 & 0.044 & 0.041 & 0.152 & & & & & \\
\hline & p-values & 0.001 & $<0.001$ & 0.116 & 0.499 & 0.544 & 0.027 & & & & & \\
\hline \multirow{2}{*}{ Mental health (MH) } & $\mathrm{r}$ & 0.157 & 0.177 & 0.211 & 0.334 & 0.314 & 0.247 & 0.142 & & & & \\
\hline & p-values & 0.011 & 0.007 & $<0.001$ & $<0.001$ & $<0.001$ & $<0.001$ & 0.031 & & & & \\
\hline \multirow{2}{*}{$\begin{array}{l}\text { Quality of life total score } \\
\text { (QOLTS) }\end{array}$} & $\mathrm{r}$ & 0.478 & 0.504 & 0.416 & 0.304 & 0.226 & 0.500 & 0.480 & 0.404 & & & \\
\hline & p-values & $<0.001$ & $<0.001$ & $<0.001$ & $<0.001$ & $<0.001$ & $<0.001$ & $<0.001$ & $<0.001$ & & & \\
\hline \multirow{2}{*}{ Internal satisfaction (IS) } & $\mathrm{r}$ & 0.137 & 0.179 & 0.121 & 0.033 & 0.137 & 0.185 & 0.253 & 0.083 & 0.246 & & \\
\hline & p-values & 0.024 & 0.005 & 0.041 & 0.570 & 0.021 & 0.002 & $<0.001$ & 0.159 & $<0.001$ & & \\
\hline \multirow{2}{*}{ External satisfaction (ES) } & $\mathrm{r}$ & 0.128 & 0.098 & 0.162 & 0.017 & 0.153 & 0.171 & 0.227 & 0.012 & 0.211 & 0.529 & \\
\hline & p-values & 0.036 & 0.129 & 0.006 & 0.774 & 0.011 & 0.005 & $<0.001$ & 0.836 & $<0.001$ & $<0.001$ & \\
\hline \multirow{2}{*}{$\begin{array}{l}\text { Job satisfaction total } \\
\text { Score (JST) }\end{array}$} & $\mathrm{r}$ & 0.143 & 0.160 & 0.143 & 0.035 & 0.157 & 0.194 & 0.263 & 0.044 & 0.260 & 0.813 & 0.744 \\
\hline & $\mathrm{p}$-values & 0.017 & 0.012 & 0.015 & 0.550 & 0.008 & 0.001 & $<0.001$ & 0.448 & $<0.001$ & $<0.001$ & $<0.001$ \\
\hline
\end{tabular}




\section{Discussion}

Today, it is known that forming a social structure consisting of compatible individuals is very important, and in this respect, recreational activities are thought to be very valuable for a society that aims to have happy individuals [18]. Recreational activities also can be defined as physical activity, social interaction, and mental relaxation. Stress prevention and the relaxing effects of leisure time are indeed in line with the psychology literature. The phenomenon of leisure time can be useful during the process of mental relaxation, with its function being emotion-focused, motivational, relaxational, satisfactional, and a partial estrangement from the realities of life through temporary independence [19]. On the other hand, to ensure the useful effects of physical activity in adults, it is recommended that adults engage in physical activity at least three times a week, for 30-60 minutes at a time and at 50\%-75\% of heart rate per minute [20]. Most of the time, this is a tempo that can be seen in optional recreational activities and is known to be very useful in terms of individual health. In addition, such activities are directly associated with individuals' quality of life. While physical exercises have a positive effect in decreasing anxiety, stress and depression, they are also considered to be among the most basic approaches in the prevention of obesity and chronic diseases [21]. Within this context, it is thought that the application and rhythm of recreational activities will make considerable contributions to the improvement of sedentary individuals' physical and mental health and thereby play an important role in increasing the percentage of healthy individuals in society. Although the total quality-of-life scores of participants were found to be below the average score (90) thought for healthy individuals, it can be said that participation in recreational activities will have positive effects on individuals' quality of life. The results of the research indicating that the individuals who participate in recreational activities have higher quality-of-life total scores than those who do not also support this view. On the other hand, it is understood from the research that the factors influencing the quality of life of individuals who participate in recreational activities are caused by the dimensions of physical function, physical role, and emotional role. Thus, it can be said that participating in recreational activities has a positive influence on quality of life. Research conducted by [22] on state employees shows that participants view leisure-time activities as relaxing, entertaining, healthy, educational, and pleasing.

Another study found that job satisfaction among employees is extremely important in terms of corporate performance (12). In this study, participation in recreational activities is found to have a $10 \%$ positive effect on participants' job-satisfaction levels (Table 2). When the associations between quality of life and job satisfaction of participants who did not participate in recreational activities were analysed, an $18.3 \%(0.260-0.077)$ increase in the percentage of individuals who participated in recreational activities, when compared with those who did not, brings to mind the thought that with the increase in participation time, quality of life and job satisfaction of state personnel can increase even more. It can be said that this can certainly help prevent emotional exhaustion, as well as prevent the development of negative attitudes toward others, thereby increasing levels of job satisfaction in the workplace. In fact, it can be seen that as levels of education and income increase, so does leisure time. This can, in turn, cause the perception of 'insufficiency of recreational activities' and become a new source of 'unhappiness' that did not previously exist. Thus, it is possible to address the obligation of the efforts to develop recreational activities to fuel efforts to increase levels of education and income [23].

In conclusion, it can be said that participation in recreational activities, which are defined as physical activities organised or done voluntarily, will have a direct influence on individuals' lifestyles and increase their quality of life and job satisfaction significantly. The results of the study support this assessment. Developing recreational programs at organisations so that they will appeal to workers seems to be extremely important. The following recommendations can be made based on the results of this study:

- A general-approach plan that influences individuals' lives should be prepared.

- Organisations should educate employees about healthy lifestyles, including exercise.

- Recreational programmes should be organised periodically in line with individuals' desires.

- In addition to motivation and quality-of-life studies on employees, their participation in recreational activities should be encouraged.

- Employees' views on how to increase job satisfaction should be seriously considered.

\section{REFERENCES}

[1] G. Torkildsen. Leisure and Recreation Management (5th ed.), Routledge, 2005.

[2] HD. Sevin, S. Küçük. İşgörenlerin rekreasyonel etkinliklere katılım düzeyleri ile çalışma performansları arasındaki ilişkiyi belirlemeye yönelik bir araştırma, Journal of Recreation and Tourism Research. Vol. 3, No. 1): 24-31, 2016. http://jrtr.org/wp-content/uploads/sevin_ve_k $\% \mathrm{C} 3 \% \mathrm{BC} \% \mathrm{C} 3$ $\% \mathrm{~A} 7 \% \mathrm{C} 3 \% \mathrm{BCk}$.pdf

[3] Wang WC, CC. Wu, CY. Wu. Early-life outdoor experiences and involvement in outdoor recreational activities in adulthood: A case study of visitors in Da-Keng, Taiwan, Journal of Quality Assurance in Hospitality and Tourism. Vol. 14 No. 1-2, 66-80, 2013.

http://www.tandfonline.com/doi/abs/10.1080/1528008X.2013 .749383 
[4] F. Lobo. The work-leisure paradigm: The stress and strains of maintaining a balanced lifestyle. World Leisure, Vol. 43, No. 3, 21-32. 2006.

http://www.tandfonline.com/doi/abs/10.1080/04419057.2006. 9674451? journalCode $=$ rwle20

[5] S Baysal Üregen. Depresyonlu Hastalarda Yaşam Kalitesi Algısının Araştırılması, Yayınlanmamış Klinik Psikoloji Programı Yüksek Lisans Tezi, İzmir, 1991.

[6] MS. Talas. Yaşam Kalitesi ve Hemşirelik Hizmetleri, III. Ulusal Sağlı ve Hastane Yönetimi Sempozyumu Bildiri Kitabı. Ankara Üniversitesi. Sarp N. (Ed.). 2000.

[7] RC. Ziller. Self-other orientations and quality of life. Social Indicators Research. Vol. 1, No. 3, 301-327, 1974. https://link.springer.com/article/10.1007/BF00303861

[8] P. Benner. Quality of life: a phenomenological perspective on explanation, prediction, and understanding in nursing science. Advances in Nursing Science. Vol. 8, No. 1, 1-14, 1985. https://www.ncbi.nlm.nih.gov/pubmed/3933410

[9] Tatar M, Tatar F. Sağlığın ölçülmesi: kavramsal bir çerçeve, Toplum ve Hekim Dergisi. Vol. 12, No. 78, 54-61, 1997. http://www.belgelik.dr.tr/ToplumHekim/get.php?download f ile $=19970215$.pdf

[10] İ. Bakan, T. Büyükbeşe. Örgütsel iletişim ile iş tatmini unsurları arasındaki ilişkiler: akademik örgütler için bir alan araştırması.

Akdeniz İ.İ.B.F. Dergisi. Vol. 7, No. 1-30, 2004. http://kutup hane.dogus.edu.tr/mvt/catalog.php? $\operatorname{lng}=0$ \&arananID=\&searc $\mathrm{h}=\% \mathrm{C} 3 \% 96 \mathrm{rg} \% \mathrm{C} 3 \% \mathrm{BCtsel}+\mathrm{ileti} \% \mathrm{C} 5 \% 9 \mathrm{Fim}+\mathrm{ile}+\mathrm{i} \% \mathrm{C} 5 \% 9 \mathrm{~F}$ + tatmini+unsurlar $\% \mathrm{C} 4 \% \mathrm{~B} 1+\operatorname{aras} \% \mathrm{C} 4 \% \mathrm{~B} 1$ ndaki+ili $\% \mathrm{C} 5 \% 9$ Fkiler\&fieldnu $=0$ \&articlelng $=\&$ sortnu $=0$ \&sortdir $=0$ \&access $=$ catalog $\&$-max $=20 \&$-skip $=0$

[11] HI. Cankul, B. Göktaş, H. Güllerci, N. Mamir. 12 th Congress of Balkan Military Medical Committee. Evaluation of Job Satisfaction of the Nurses and Midwives Working in Agri Region (p: 249). Romanian National Board of B.M.M.C. 24-28 June. Poiana Brasov'da-Romanıa, 2007.

[12] G. Çavuşoğlu, MY. Tasmektepligil, I. Islamoglu, S. Unver. Evaluation of the job satisfaction levels of the personnel who worked in sports organızation Journal of Social Sciences Research. Vol. 9, No. 2, 1858-1866, 2015. https://cirworld.com/index.php/jssr/article/view/4941/4810

[13] A. Aksungur. Dr. Zekai Tahir Burak Kadın Sağlığı Eğitim ve Araştırma Hastanesinde Çalışan Ebe ve Hemşirelerin İs Doyumu ve Yaşam Kalitesi Düzeylerinin Belirlenmesi, Hacettepe Üniversitesi, Sağlık Bilimleri Enstitüsü, Sağlık Yönetimi Programı. Yüksek Lisans Tezi, 2009.
[14] H. Kocyigit, Ö. Aydemir, N. Ölmez, A. Memis. Kısa Form-36 (KF- 36)'nın Türkçe versiyonunun güvenilirliği ve geçerliliği, İlaç ve Tedavi Dergisi. Vol. 12, 102-106, 1999.

[15] CS. Burckhardt, KL. Anderson. The Quality of Life Scale (QOLS): reliability, validity, and utilization. Health and quality of life outcomes. Vol. 1, No. 60, 1-7, 2003. https://www.ncbi.nlm.nih.gov/pubmed/14613562

[16] DJ. Weiss, RV. Dawis, GW. England, LH. Lofquist. Manual for the Minnesota Satisfaction Questionnaire. Vol. 22, Minnesota Studies in Vocational Rehabilitation, Minneapolis: University of Minnesota, Industrial Relations Center. 1967.

[17] R. Altunışık, R. Coşkun, E Yıldırım, S Bayraktaroğlu. Sosyal Bilimlerde Araştırma Yöntemleri SPSS Uygulamal, Sakarya Kitabevi, ISBN: 978-975-8644-80-3, Beșinci Baskı, Sakarya. 2007.

[18] AK. Gürbüz. Lisans Düzeyinde Eğitimde Rekreasyon Yönetimi Bölümü'nün Anlamı, İçermesi Gereken Dersler ve Gerekçeleri Üzerine Manifesto, Balıkesir, Liva Yayınları. 2015.

[19] Y. Iwasaki, IE. Schncider. Leisure, stress and coping: An evolving area of inquiry, Leisure Sciences. Vol. 25, No. 2-3, 107-113, 2003.

http://www.tandfonline.com/doi/abs/10.1080/0149040030656

[20] SA. Vaizoğlu, O. Akça, A. Akdă̆, A. Akpınar, AH. Omar, D. Coşkun, Ç. Güler. Genç erişkinlerde fiziksel aktivite düzeyinin belirlenmesi, Türk Silahlı Kuvvetleri Koruyucu Hekimlik Bülteni. Vol. 3, No. 4, 63-71, 2004.http://www.ejm anager.com/mnstemps/1/khb_003_04_63.pdf

[21] WHO. Addressing the Socioeconomic Determinants of Healthy Eating Habits and Physical Activity Levels among Adolescents. 2006, Date accessed: 27 Augusts 2009. http://www.euro.who.int/document/e89375.pdf.

[22] S. Özdağ, M. Yeniçeri, İB. Fişekçioğlu, F. Akçakoyun, R. Kürkçü. Devlet memurlarının boș zaman değerlendirme eğilimleri, antropometrik ve fiziksel uygunluk seviyeleri, Selçuk Üniversitesi Sosyal Bilimler Enstitüsü Dergisi. Vol. 22, 307-323, 2009.

http://dergisosyalbil.selcuk.edu.tr/susbed/article/view/290

[23] SB. Yıldız, SN. Kılıç, AK. Gürbüz. Balıkesir kent halkının yaşadıkları kentteki rekreasyon faaliyetlerine katılımları ve yerel rekreasyon imkanlarının yeterlilik düzeylerinin belirlenmesi, Journal of Recreation and Tourism Research. Vol. 3, No. 1, 10-23, 2016. http://jrtr.org/wp-content/uploads/ y\%C4\%B11d\%C4\%B1z-vd.pdf 